\title{
A primate-specific short GluN2A-NMDA receptor isoform is expressed in the human brain
}

\author{
Hannah Warming ${ }^{1}$, Chrysia-Maria Pegasiou', Aleksandra P. Pitera' ${ }^{1}$, Hanna Kariis' ${ }^{1}$, Steven D. Houghton', \\ Ksenia Kurbatskaya ${ }^{1}$, Aminul Ahmed ${ }^{2}$, Paul Grundy ${ }^{2}$, Girish Vajramani ${ }^{1,2}$, Diederik Bulters ${ }^{1,2}$, Xavier Altafaj ${ }^{3}$, \\ Katrin Deinhardt ${ }^{1}$ and Mariana Vargas-Caballero ${ }^{1 *}$ (D)
}

\begin{abstract}
Glutamate receptors of the N-methyl-D-aspartate (NMDA) family are coincident detectors of pre- and postsynaptic activity, allowing $\mathrm{Ca}^{2+}$ influx into neurons. These properties are central to neurological disease mechanisms and are proposed to be the basis of associative learning and memory. In addition to the well-characterised canonical GluN2A NMDAR isoform, large-scale open reading frames in human tissues had suggested the expression of a primate-specific short GluN2A isoform referred to as GluN2A-S. Here, we confirm the expression of both GluN2A transcripts in human and primate but not rodent brain tissue, and show that they are translated to two corresponding GluN2A proteins present in human brain. Furthermore, we demonstrate that recombinant GluN2A-S co-assembles with the obligatory NMDAR subunit GluN1 to form functional NMDA receptors. These findings suggest a more complex NMDAR repertoire in human brain than previously thought.
\end{abstract}

Keywords: NMDA receptor, Synapses, Human, Primate, Resected, Neurosurgery, PSD-95, Glutamatergic

\section{Introduction}

NMDA receptors are activated by coincident glutamate binding and intracellular depolarisation. $\mathrm{Ca}^{2+}$ entry via NMDARs can gate long-term biochemical and gene expression changes that alter synaptic strength, which are proposed as central to mechanisms of memory storage [17] and neurodegenerative processes [9]. Our current knowledge of NMDAR function is largely derived from the study of rodent receptors and heterologous expression of cloned rodent genes. Tetrameric NMDARs comprise two obligatory GluN1 subunits and two GluN2 or GluN3 subunits, and in the adult forebrain GluN1/GluN2A, GluN1/GluN2B diheteromers, and GluN1/GluN2A/ GluN2B triheteromers are the most common $[18,19]$. The subunit combination confers the distinct biophysical and pharmacological properties to the receptor channel. The developmentally and anatomically regulated gene expression of NMDAR subunits, together with diverse post-

\footnotetext{
* Correspondence: m.vargas-caballero@soton.ac.uk

${ }^{1}$ School of Biological Sciences, University of Southampton, University Road, Southampton SO17 1BJ, UK

Full list of author information is available at the end of the article
}

translational modification mechanisms and protein interactions, determines the assembly, trafficking, synaptic or extrasynaptic localisation and internalisation of NMDARs (Reviewed in [16]) and their correct functioning is necessary for human brain functions $[5,6,21]$.

Homologous rodent and human NMDARs do share highly conserved subunit sequences and exhibit almost identical pharmacological properties [10]. However, large scale open reading frame studies performed with mRNA from a mix of human tissues $[20,28]$ have suggested that in addition to the conserved NMDAR canonical isoform of GluN2A in chordates, a shorter isoform is produced in humans (GluN2A-S) generated by alternative splicing of human GRIN2A (Fig. 1a). Here, we show that this alternative NMDAR isoform is expressed in the human and primate brain, and that it forms functional receptors together with the obligatory subunit GluN1 [15]. The presence of alternative NMDAR subunits not expressed in rodent model systems indicates the existence of unexplored neural mechanisms in human synapses with relevance to normal function, ageing and neurological disease.

(C) The Author(s). 2019 Open Access This article is distributed under the terms of the Creative Commons Attribution 4.0 International License (http://creativecommons.org/licenses/by/4.0/), which permits unrestricted use, distribution, and reproduction in any medium, provided you give appropriate credit to the original author(s) and the source, provide a link to the Creative Commons license, and indicate if changes were made. The Creative Commons Public Domain Dedication waiver (http://creativecommons.org/publicdomain/zero/1.0/) applies to the data made available in this article, unless otherwise stated. 


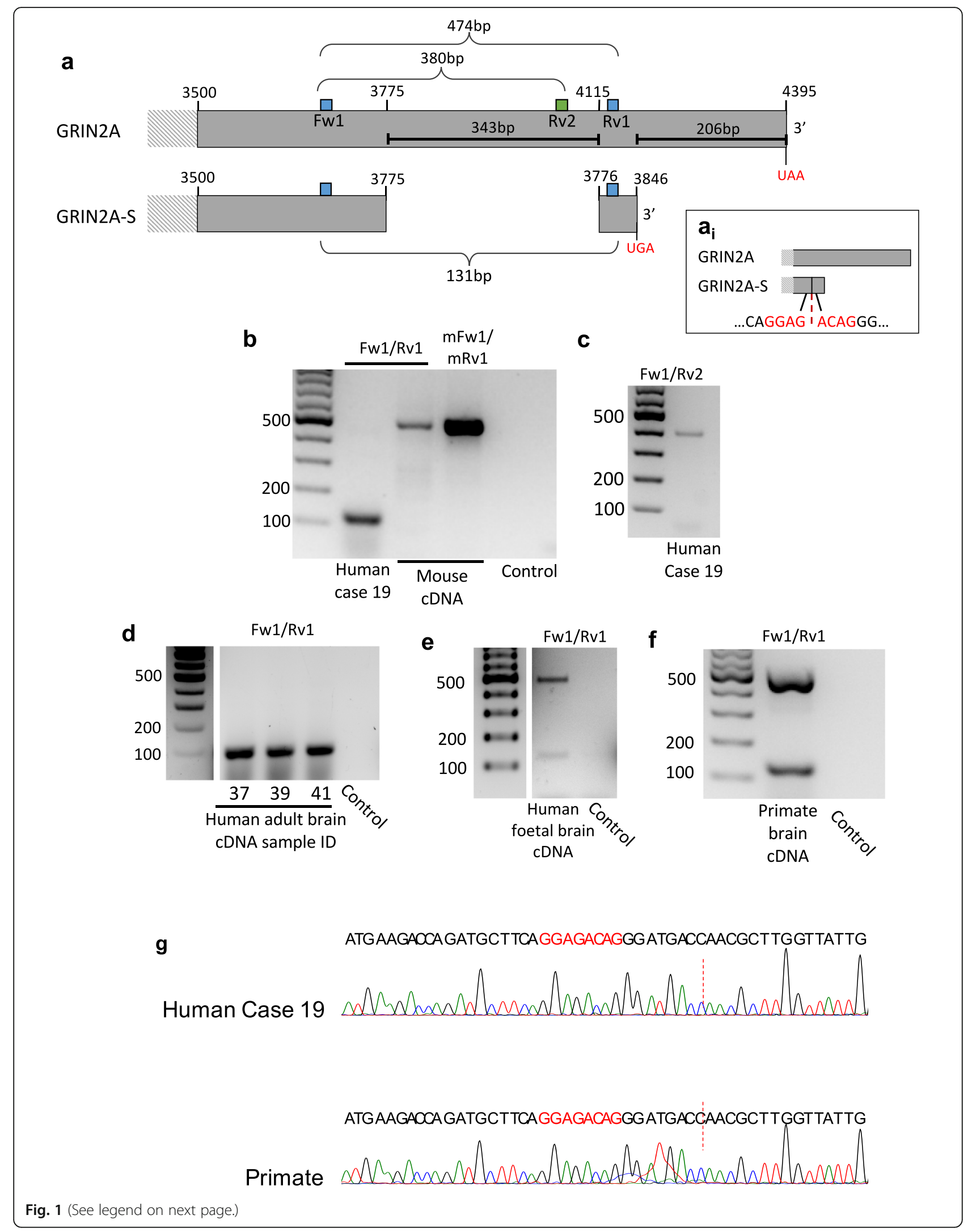


(See figure on previous page.)

Fig. 1 The GRIN2A gene has two transcript variants in human and primate but not mouse brain. a A short isoform of GRIN2A transcript was predicted by open reading frame studies. The published sequence of GRIN2A-S suggests that the final exon (exon 13) is missing two nucleotide regions compared to the canonical transcript: firstly, the lack of 343 nucleotides generates a putative exon 14 in GRIN2A-S (splice site shown in $A_{i}$ ) and the final 206 nucleotides of the canonical form are lost altogether. We designed primers to amplify the region of variance between the two isoforms (Fig. 1, Fw1/Rv1) generating an amplicon of $474 \mathrm{bp}$ in GRIN2A and $131 \mathrm{bp}$ in GRIN2A-S. A second reverse primer was designed to amplify canonical GRIN2A selectively (Fig. 1a, Rv2) generating an amplicon of $380 \mathrm{bp}$. b-f RT-PCR amplification end products. Control conditions indicate no cDNA template was used in PCR $\mathbf{b}$ In human CDNA, only the short form of GRIN2A was observed likely due to preferential amplification in PCR, whereas only a long product of $474 \mathrm{bp}$ was seen in mouse using either human or mouse specific primers. c The Fw1/Rv2 primer pair was used to confirm expression of canonical GRIN2A in the same human sample as shown in (B). $\mathbf{d} 3$ other human cortical samples with GRIN2A-S amplified. e Both the short and long amplicons were observed in human foetal CDNA. f GRIN2A-S was observed in primate (Rhesus) brain cDNA. g Sequencing of human and primate RT-PCR short amplicons confirmed the presence of the putative splice site shown in Ai

\section{Results and discussion}

To test whether the GluN2A-S mRNA (GRIN2A) is expressed in human brain, we designed primers (Fw1/ Rv1) flanking the region of exon 13 containing the 343 base pairs (bp) present only in GRIN2A (Fig. 1a). We predicted two distinct amplicons (474 bp and $131 \mathrm{bp}$ ) that would distinguish the GRIN2A and GRIN2A-S transcripts, respectively (Fig. 1a). Following PCR using cDNA from human brain (Table 1) as template, we observed the presence of a $\sim 131 \mathrm{bp}$ amplicon. In contrast, in mouse we observed one product of $474 \mathrm{bp}$, corresponding to the canonical isoform, using Fw1/Rv1 primers and a pair of primers modified to exactly match mouse Grin $2 A$ at the same location (mFw1/mRv1, Fig. 1b). If both short and long GRIN2A cDNAs are present in the human sample, the synthesis of shorter cDNA could overwhelm the early PCR cycles [27] and only generate the short amplicon. Using an additional GRIN2A specific reverse primer (Rv2), we confirmed the presence of canonical GRIN2A in this human cDNA sample (Fig. 1c). We observed the $131 \mathrm{bp}$ band in further adult brain cDNAs tested with Fw1/Rv1 primer pair (Fig. 1d, two further samples not shown). Although its expression levels increase developmentally, GluN2A is expressed throughout the life course [2]. We tested foetal human brain cDNA and confirmed the expression of both GRIN2A and GRIN2A-S (Fig. 1e).

Table 1 Details of resected human brain tissue samples

\begin{tabular}{|c|c|c|c|}
\hline Case Number & Sex & Age & Reason for Surgery \\
\hline 004 & M & 52 & Hippocampal sclerosis \\
\hline 007 & $\mathrm{~F}$ & 21 & DNET \\
\hline 008 & M & 71 & Glioblastoma \\
\hline 010 & M & 28 & Hippocampal sclerosis \\
\hline 011 & $\mathrm{~F}$ & 42 & Glioma \\
\hline 014 & M & 32 & Hippocampal sclerosis \\
\hline 016 & $\mathrm{~F}$ & 36 & Hippocampal sclerosis \\
\hline 017 & $\mathrm{~F}$ & 62 & Hippocampal sclerosis \\
\hline 018 & M & 30 & Cavernous malformation \\
\hline 019 & M & 19 & Arteriovenous malformation \\
\hline 020 & $\mathrm{~F}$ & 70 & Arteriovenous malformation \\
\hline 021 & M & 49 & Hippocampal sclerosis \\
\hline 022 & $\mathrm{~F}$ & 58 & Subarachnoid haemorrhage \\
\hline 024 & $\mathrm{~F}$ & 50 & Cavernous malformation \\
\hline 026 & M & 27 & Mesial temporal DNET with signal changes in the hippocampus \\
\hline 028 & $\mathrm{~F}$ & 38 & Epilepsy \\
\hline 030 & M & 40 & Cortical dysplasia \\
\hline 032 & $\mathrm{~F}$ & 29 & Tumour resection \\
\hline 037 & M & 52 & Glioma \\
\hline 039 & $\mathrm{~F}$ & 58 & Tumour resection \\
\hline 041 & M & 41 & Hippocampal sclerosis \\
\hline
\end{tabular}



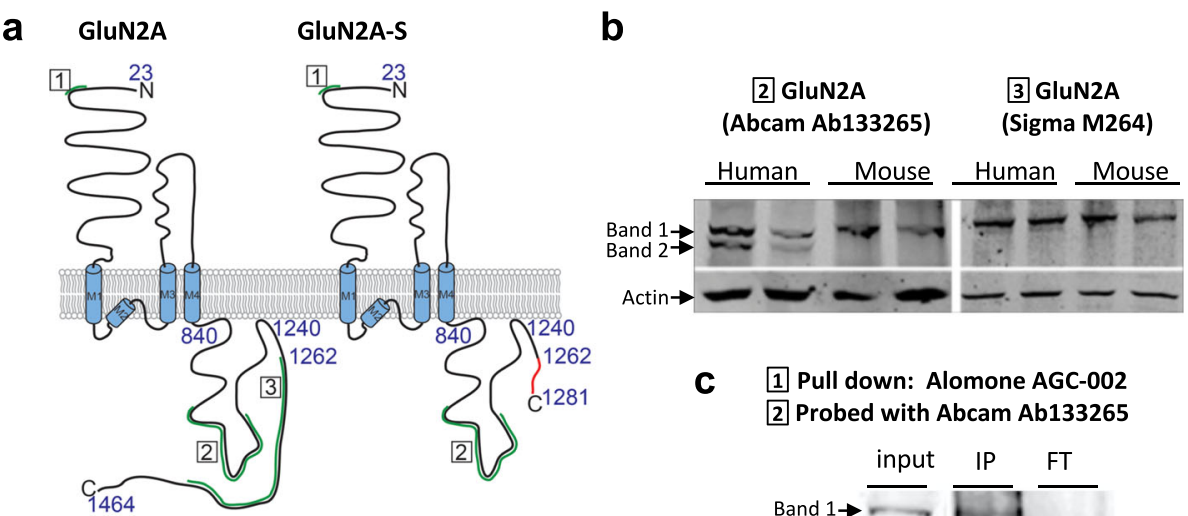

C 1 Pull down: Alomone AGC-002 2 Probed with Abcam Ab133265

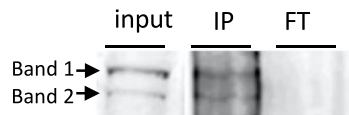

d

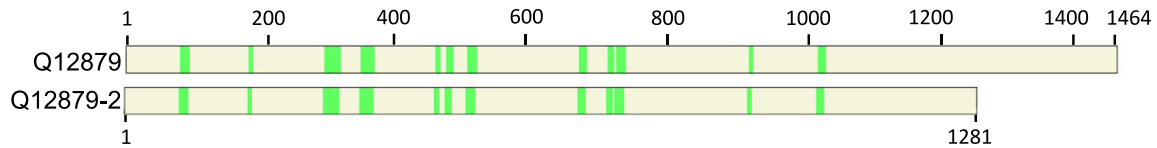

$\mathbf{e}_{\mathbf{i}}$

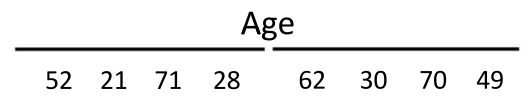

$\mathbf{f}_{\mathbf{i}}$
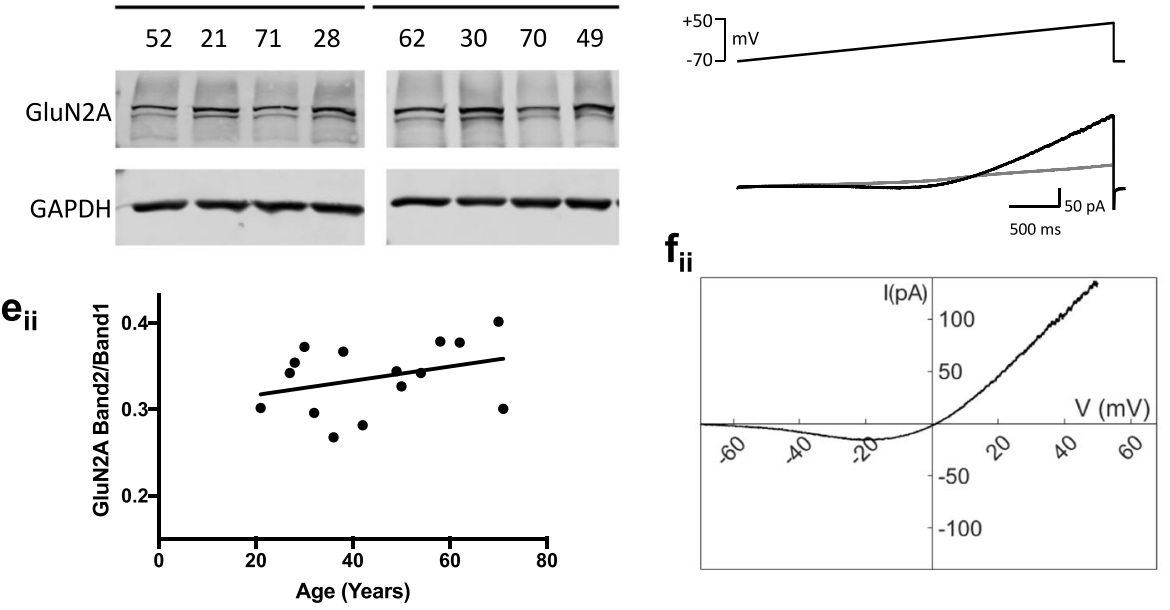

Fig. 2 Two GluN2A protein bands are observed in human but not mouse brain. a Topology of the GluN2A subunit of the NMDA receptor and of GluN2A-S predicted from human mRNA studies. A spliced region is retained in canonical GluN2A leading to an alteration of the reading frame to generate a diverging C-terminal sequence (red) with early truncation. Epitopes for the antibodies used are shown in green and are numbered. $\mathbf{b}$ Immunoblots with specific antibodies against the canonical GluN2A and putative GluN2A-S protein in human and mouse cortical lysates. c GluN2A proteins were pulled down with an N-terminal antibody. Band 2 was cut from Coomassie-stained polyacrylamide gel and analysed by mass spectrometry. IP, immunoprecipitate. FT, flowthrough d A set of 14 peptides were confirmed to be present in this band. Figure shows tryptic peptides from band 2 coverage to either canonical GluN2A amino acid sequence (Uniprot: Q12879) or GluN2AS (Q12879-2, predicted) confirming band 2 contains GluN2A protein. e Homogenate from freshly frozen cortical human tissue probed with the GluN2A antibody Abcam 133,265 (select blots shown on top) and quantification of GluN2A-S / GluN2A immunoreactivity (bottom). See Table 1 for human tissue sample details. f Recombinant GluN2A-S co-expressed with GluN1 in HEK293 cells produces functional NMDARs as demonstrated by a typical J-shaped curve in response to $40 \mathrm{mM} N \mathrm{NDA}$ in response to a slow ramp of voltage $(-70$ to $+50 \mathrm{mV}, 3 \mathrm{~s})$

Thus, our data confirm the presence of both canonical GRIN2A and the novel GRIN2A-S transcripts in human brain tissue samples.

A BLAST search of the 131 bp sequence amplified by primers Fw1/Rv1 provided primate-specific predictive hits. To confirm whether GRIN2A-S transcript is present in primate brain, we tested Rhesus macaque brain cDNA with Fw1/Rv1 primers and confirmed the presence of GRIN2A-S (Fig. 1f). We sequenced the shorter PCR products for both the adult human and primate samples and confirmed the presence of the exact splice site reported in the European Nucleotide Archive (Coding: AAI17132.1; [20] (Fig. 1a,g).

Furthermore, we aimed to evaluate whether the GRIN2A and GRIN2A-S transcripts were translated into the corresponding proteins. To this end, we hypothesised that if both transcripts are translated into proteins, two protein bands corresponding to GluN2A and 
GluN2A-S in human homogenate would be immunodetected by a GluN2A antibody targeting an epitope conserved between the canonical and short GluN2A isoforms (Fig. 2a,b). Importantly, Western blot analysis from human brain homogenates confirmed the presence of two immunoreactive bands with a molecular weight corresponding to the predicted GluN2A and GluN2A-S isoforms. On the contrary, a single immunoreactive band with the high molecular weight (corresponding to the canonical GluN2A) was detected in mouse brain lysates (Fig. 2b). Furthermore, using an antibody specifically detecting a carboxy terminal epitope (exclusively present in the canonical GluN2A isoform), we detected the presence of a single band, with a molecular weight corresponding to the canonical GluN2A subunit (Fig. 2a, b). To confirm the identity of the low molecular weight band, we immunoprecipitated GluN2A from human tissue homogenates with an antibody against the conserved $\mathrm{N}$-terminal domain and analysed the primate-specific band (Band 2, Fig. 2c) by mass spectrometry. This unbiased method allowed the identification of 14 unique peptides located within GluN2A residues 81-1022, confirming that this low molecular band contains the proximal part of GluN2A, and thus discarding the potential cross-reactivity of anti-GluN2A N-terminal antibody (Fig. 2d). To assess the relative levels of GluN2A-S vs. total GluN2A, human cortical homogenates from freshfrozen tissue resected from individuals 27-61 years of age were analysed by Western blot and the quantification showed that GluN2A-S immunoreactivity accounts for $34 \pm 4 \%$ of canonical GluN2A protein in cortical human brain homogenate (Table 1) and this fraction remains constant across age (Fig. 2ei).

Finally, to test whether GluN2A-S can be incorporated into functional NMDARs, we co-transfected HEK293 cells with plasmids expressing GluN2A-S and GluN1 subunits [15]. A slow voltage ramp delivered during local perfusion with $40 \mu \mathrm{M}$ NMDA and $10 \mu \mathrm{M}$ glycine elicited a typical Jshaped curve (Fig. 2fi), and subtraction of responses without agonist (leak subtraction) revealed a typical NMDA current with reversal potential near $0 \mathrm{mV}$ (Fig. 2eii). This confirms that GluN2A-S subunits are able to assemble with GluN1 subunits and become inserted into the plasma membrane to form a functional NMDAR that likely plays a role in human neural function.

Here we describe for the first time the brain expression of an uncharacterised, primate-specific NMDAR subunit. The splice site for GluN2A-S suggests that it will contain a diverging 19 aa sequence in its extreme Cterminal domain (Fig. 2a), in addition to lacking the distal carboxy terminal domain (183 amino acids) that contains PKC/SFK phosphorylation sites, two PDZ binding motifs that allow synaptic localisation [4, 12, 14], and a dileucin clathrin adaptor motif involved in receptor internalisation [13]. Following many lines of published evidence, these differences suggest that the dynamic regulation of GluN2A-S in response to stimuli could diverge from GluN2A subunit-containing NMDARs. This could impact the number of receptors present synaptically or extrasynaptically, the insertion of new receptors into the membrane, their lateral diffusion and clustering into synapses and their active removal. The potential changes in human synapses compared to mouse neurons void of GluN2A-S could result in distinct mechanisms involved in activity-dependent plasticity of synapses, which will highly depend upon its triheteromeric partners $[1,8,19]$.

Together, our data suggest that GluN2A-S is a primatespecific NMDAR subunit and a substantial component of functional NMDARs in the adult human brain. Many neuronal mechanisms discovered in mice have been successfully recapitulated in humans. However, mounting evidence suggests that there are important differences between rodent and human neurons that result in distinct signal integration properties $[22,23,26]$ and proteomic composition of synapses [3]. Species differences may ultimately impact the way in which human neural circuits can be computationally modelled [7], and the translation of pre-clinical findings into approved therapies [24]. Further analyses of GluN2A-S spatio-temporal gene expression and synaptic/ extrasynaptic localisation will enhance our knowledge of their functional role and may uncover NMDAR trafficking mechanisms present only in primates and diverging sequences may uncover novel therapeutic targets.

\section{Materials and methods}

\section{Human brain tissue samples}

All samples consisted of cortical tissue resected for access to deeper brain lesions such as sclerotic hippocampus in epileptic patients (the pathological tissue for these lesions was not used). Informed consent was obtained from all patients to use surgically-resected putatively non-pathological tissue not required for diagnostic purposes (see ethical approval declaration). Briefly, resected tissue was obtained from temporal cortex of patients undergoing surgery for the removal of deeper structures. Tissue was collected in ice cold artificial cerebrospinal fluid [26] then taken to the laboratory, frozen and kept at $-80^{\circ} \mathrm{C}$. Transfer time was of the order of $10-15 \mathrm{~min}$.

\section{Mouse brain tissue}

Mice were decapitated following isoflurane anaesthesia (see ethical approval declaration). Brains were extracted in ice-cold ACSF and sliced or snap-frozen. All brain tissue samples were stored in the $-80 \mathrm{C}$ freezer until lysed.

\section{RNA extraction and CDNA synthesis}

Total RNA was isolated from human and mouse tissue using Trizol and then purified using the RNeasy Mini kit 
(QIAGEN) following the manufacturer's instructions. cDNA was synthesised immediately from $200 \mathrm{ng}$ of total RNA per reaction using the SuperScript IV reverse transcriptase and cDNA synthesis kit (INVITROGEN) according to the manufacturer's instructions. The cDNA obtained was stored at $-80^{\circ} \mathrm{C}$. Human foetal cDNA was obtained from Takara (Normal brain tissue cDNA, pooled from 59 spontaneously aborted male/ female Caucasian fetuses, ages: 20-33 weeks). Rhesus macaque cDNA was obtained from Amsbio (Normal brain tissue, Female, 4.5 years).

\section{PCR conditions and primers}

PCR was performed on $1 \mu \mathrm{g}$ of cDNA using primers and REDTaq $^{\circ}$ Readymix ${ }^{\text {Tw }}$ PCR Reaction Mix (Sigma-Aldrich) for 40 cycles. DNA was denatured at 95 degree $C$ and extended at 72 degree $C$ for $45 \mathrm{~s}$ each cycle. Products were separated on a $1.5 \%$ agarose gel.

The following primers were used: Fw1: ATTCAGGCCACTTCACCATGAG, Rv1: ATCTCCCAATAACCAAGCGTTG, Rv2: CTTGCTGTCCTCCAGACCTTGG mFw1: ACTCAGGCCACTTTACCATGAG, and mRv1: ATCTCCCAATAACTAAGCGTTG.

\section{Plasmids}

pEYFP-NR1a was a gift from Stefano Vicini (Addgene plasmid \# 17928; [15]). GRIN2A-S plasmid from Broad Institute, was acquired from Source Bioscience (Transcript NM_001134408.2).

\section{Western blotting}

Equal amounts of protein $(28 \mu \mathrm{g})$ were separated in $7.5 \%$ acrylamide gels by SDS-PAGE and transferred onto nitrocellulose membranes. Membranes were blocked in 5\% $(\mathrm{w} /$ v) non-fat milk for $1 \mathrm{~h}$ at room temperature and incubated overnight at $4 \mathrm{C}$ in $5 \%(\mathrm{w} / \mathrm{v})$ bovine serum albumin (BSA) containing $0.1 \%(\mathrm{v} / \mathrm{v})$ Tween-20 and one of the following primary antibodies: anti-NMDAR2A (ab133265; 1:1000; Abcam); and GAPDH (D16H11; 1:1000; CST) actin. Membranes were washed 3 times with Tris-buffered saline (TBS) containing $0.1 \%$ Tween-20 (TBS-T) and probed with fluorophore-conjugated goat anti-mouse/-rabbit secondary antibody (1:10000; LI-COR). Proteins were visualised using the Odyssey infrared scanner (LI-COR) using Image Studio Light Software.

\section{GluN2A pulldown}

GluN2A was pulled down from $1 \mathrm{mg}$ of protein homogenate (in RIPA buffer) using $2 \mu \mathrm{g}$ of Alomone antibody AGG-002 beads. Eluate was run in SDS page and stained with Coomassie dye. The lighter band corresponding to putative GluN2A-S was cut and analysed by LC-MS/MS [11].

\section{HEK293T cell recordings}

HEK293T cells were cultured at $37 \mathrm{C}$ with $5 \% \mathrm{CO}_{2}$ in Dulbecco's Modified Eagle Medium with glucose, Lglutamine and pyruvate, 10\% FBS and 1\% Pen-Strep and seeded at low density onto poly-L-lysine coated glass coverslips for electrophysiology. Adherent cells were transfected using JetPEI reagent with NR1a and GluN2A-S plasmids at a 1:1 ratio and recorded after 48 h. Borosilicate glass micropipettes were pulled to produce a resistance of 4-6 mOhm and filled with intracellular recording solution containing in $\mathrm{mM}$ : Gluconic acid 70, Caesium chloride 10, sodium chloride 5, BAPTA 10, HEPES 10, GTP 0.3 ATP 4 and pH balanced to 7.3 with caesium hydroxide. Cells were perfused with aCSF throughout recording containing, in mM: sodium chloride 126, calcium dichloride 2, glucose 10 , magnesium sulfate 2 , potassium chloride $3, \mathrm{NaH}_{2} \mathrm{PO}_{4} 1.25$ and $\mathrm{NaHCO}_{3}$ 26.4, and glycine $10 \mu \mathrm{M}$ and $\mathrm{pH}$ regulated by continuous bubbling of $95 \%$ oxygen, $5 \% \mathrm{CO}_{2}$. Recordings with or without addition of NMDA $40 \mu \mathrm{M}$ were made in whole-cell voltage clamp and Matlab software and amplified using an Axopatch 200B as previously described [28].

\section{Abbreviations \\ bp: Base pairs; cDNA: Copy deoxyribose nucleic acid; GAPDH: Glyceraldehyde 3-phosphate dehydrogenase; LC-MS: Liquid chromatography - mass spectrometry; mRNA: Messenger ribonucleic acid; NMDA: N-methyl-D- aspartate; NMDAR: N-methyl-D-aspartate receptor; PCR: Polymerase chain reaction; SDS-PAGE: Sodium dodecyl sulfate polyacrylamide gel electrophoresis}

\section{Acknowledgements}

We thank Dr. Kate J Heesom from the Proteomics Facility, University of Bristol for advising on and performing the mass spectrometry analysis. We thank Dr. Ian Galea as chief investigator of the NOll study.

\section{Authors' contributions}

MVC, KD, XA, HW designed research; HW, CMP, AP, HK, SDH, KK and MVC performed research; HW, CMP, AP, KK, MVC analyzed data; $D B, A A, P G, G V$ performed neurosurgery to resect human brain tissue used in this work, MVC, KD, HW wrote the paper. All authors revised and approved the manuscript.

\section{Funding}

MVC was funded by the Institute for Life Sciences (IfLS) and Wessex Innovation Fund. HW was funded by an Alzheimer's Research UK Southcoast Network Summer Studentship, HW and CMP PhD studentships were funded by the Gerald Kerkut Trust, CMP was co-funded by IfLS studentship, KK and AP were funded by Alzheimer's Society, KD was funded by BBSRC [BB/ L007576/1].

\section{Availability of data and materials}

The datasets used and/or analysed during the current study are available from the corresponding author on reasonable request.

\section{Ethics approval and consent to participate}

Anonymised human brain tissue samples: All patients provided informed consent for participation. Ethical approval: REC Reference: 12/NW/0 794, HTA LN: 12009 under the Southampton Biorepository Research. Study reference number: SRB002/14 or the NOll study: REC reference: 11/SC/0204

Sponsor number: RHM NEU0169. 
Animal tissue: Animal care and experimental procedures were conducted in accordance with UK Home Office regulations under the Animals (Scientific Procedures) Act of 1986

\section{Consent for publication}

Not applicable.

\section{Competing interests}

The authors declare that the research was conducted in the absence of any commercial or financial relationships that could be construed as a potential conflict of interest.

\section{Author details}

${ }^{1}$ School of Biological Sciences, University of Southampton, University Road, Southampton SO17 1BJ, UK. ${ }^{2}$ Wessex Neurological Centre, University Hospital Southampton, University of Southampton, Southampton, SO16 6YD, UK. ${ }^{3}$ Neuropharmacology Unit, Bellvitge Biomedical Research Institute (IDIBELL), L'Hospitalet de Llobregat, Barcelona, Spain.

\section{Received: 4 June 2019 Accepted: 21 June 2019}

\section{Published online: 04 July 2019}

\section{References}

1. Al-Hallaq RA, Conrads TP, Veenstra TD, Wenthold RJ. NMDA Di-Heteromeric receptor populations and associated proteins in rat Hippocampus. J Neurosci. 2007;27:8334-43.

2. Bar-Shira O, Maor R, Chechik G. Gene expression switching of receptor subunits in human brain development. PLoS Comput Biol. 2015;11: e1004559.

3. Bayés A, Collins MO, Croning MDR, van de Lagemaat LN, Choudhary JS, Grant SGN. Comparative study of human and mouse postsynaptic proteomes finds high compositional conservation and abundance differences for key synaptic proteins. PLoS One. 2012;7:e46683.

4. Cousins SL, Kenny AV, Stephenson FA. Delineation of additional PSD-95 binding domains within NMDA receptor NR2 subunits reveals differences between NR2A/PSD-95 and NR2B/PSD-95 association. Neuroscience. 2009;158:89-95

5. de Ligt J, Willemsen MH, van Bon BWM, Kleefstra T, Yntema HG, Kroes T, Vulto-van Silfhout AT, Koolen DA, de Vries P, Gilissen C, del Rosario M, Hoischen A, Scheffer H, de Vries BBA, Brunner HG, Veltman JA, Vissers LELM. Diagnostic exome sequencing in persons with severe intellectual disability. N Engl J Med. 2012;367:1921-9.

6. Endele S, Rosenberger G, Geider K, Popp B, Tamer C, Stefanova I, Milh M, Kortüm F, Fritsch A, Pientka FK, Hellenbroich Y, Kalscheuer VM, Kohlhase J, Moog U, Rappold G, Rauch A, Ropers H-H, von Spiczak S, Tönnies H, Villeneuve N, Villard L, Zabel B, Zenker M, Laube B, Reis A, Wieczorek D, Van Maldergem L, Kutsche K. Mutations in GRIN2A and GRIN2B encoding regulatory subunits of NMDA receptors cause variable neurodevelopmental phenotypes. Nat Genet. 2010;42:1021-6.

7. Eyal G, Verhoog MB, Testa-Silva G, Deitcher Y, Lodder JC, Benavides-Piccione R, Morales J, DeFelipe J, de Kock CP, Mansvelder HD, Segev I. Unique membrane properties and enhanced signal processing in human neocortical neurons. Elife. 2016:5:1-18.

8. Hansen KB, Ogden KK, Yuan H, Traynelis SF. Distinct functional and pharmacological properties of Triheteromeric GluN1/GluN2A/GluN2B NMDA receptors. Neuron. 2014:81:1084-96.

9. Hardingham GE, Bading H. Synaptic versus extrasynaptic NMDA receptor signalling: implications for neurodegenerative disorders. Nat Rev Neurosci. 2010;11:682-96.

10. Hedegaard MK, Hansena KB, Andersena KT, Bräuner-Osborne H, Traynelis SF. Molecular pharmacology of human NMDA receptors. Neurochemistry International. 2012;61(4):601-9.

11. Jiménez-Castellanos J-C, Wan Nur Ismah WAK, Takebayashi Y, Findlay J, Schneiders T, Heesom KJ, Avison MB. Envelope proteome changes driven by RamA overproduction in Klebsiella pneumoniae that enhance acquired $\beta$-lactam resistance. J Antimicrob Chemother. 2018;73:88-94.

12. Köhr G, Jensen V, Koester HJ, AL a M, Utvik JK, Kvello A, Ottersen OP, Seeburg PH, Sprengel $R$, Hvalby $\varnothing$. Intracellular domains of NMDA receptor subtypes are determinants for long-term potentiation induction. J Neurosci. 2003;23:10791-9.
13. Lavezzari G. Subunit-specific regulation of NMDA receptor endocytosis. Neurosci. 2004;24:6383-91.

14. Lim IA, Merrill MA, Chen Y, Hell JW. Disruption of the NMDA receptor-PSD95 interaction in hippocampal neurons with no obvious physiological shortterm effect. Neuropharmacology. 2003;45:738-54.

15. Luo J-H, Fu Z-Y, Losi G, Kim BG, Prybylowski K, Vissel B, Vicini S. Functional expression of distinct NMDA channel subunits tagged with green fluorescent protein in hippocampal neurons in culture. Neuropharmacology. 2002;42:306-18.

16. Lussier MP, Sanz-Clemente A, Roche KW. Dynamic regulation of NMDA and AMPA receptors by posttranslational modifications. J Biol Chem. 2015;290: jbc.R115.652750.

17. Martin SJ, Grimwood PD, Morris RGM. Synaptic plasticity and memory: an evaluation of the hypothesis. Annu Rev Neurosci. 2000;23:649-711. https:// doi.org/10.1146/annurev.neuro.23.1.649.

18. Paoletti P, Bellone C, Zhou Q. NMDA receptor subunit diversity: impact on receptor properties, synaptic plasticity and disease. Nat Rev Neurosci. 2013;14:383-400.

19. Rauner C, Köhr G. Triheteromeric NR1/NR2A/NR2B receptors constitute the major $\mathrm{N}$-methyl-D-aspartate receptor population in adult hippocampal synapses. J Biol Chem. 2011;286(9):7558-66.

20. Strausberg RL, Feingold EA, Grouse LH, Derge JG, Klausner RD, Collins FS, Wagner L, Shenmen CM, Schuler GD, Altschul SF, Zeeberg B, Buetow KH, Schaefer CF, Bhat NK, Hopkins RF, Jordan H, Moore T, Max SI, Wang J, Hsieh F, Diatchenko L, Marusina K, Farmer AA, Rubin GM, Hong L, Stapleton M, Soares MB, Bonaldo MF, Casavant TL, Scheetz TE, Brownstein MJ, Usdin TB, Toshiyuki S, Carninci P, Prange C, Raha SS, Loquellano NA, Peters GJ, Abramson RD, Mullahy SJ, Bosak SA, McEwan PJ, McKernan KJ, Malek JA, Gunaratne PH, Richards S, Worley KC, Hale S, Garcia AM, Gay L, Hulyk SW, Villalon DK, Muzny DM, Sodergren EJ, Lu X, Gibbs RA, Fahey J, Helton E, Ketteman M, Madan A, Rodrigues S, Sanchez A, Whiting M, Madan A, Young AC, Shevchenko Y, Bouffard GG, Blakesley RW, Touchman JW, Green ED, Dickson MC, Rodriguez AC, Grimwood J, Schmutz J, Myers RM, Butterfield YSN, Krzywinski MI, Skalska U, Smailus DE, Schnerch A, Schein JE, Jones SJM, Marra MA. Generation and initial analysis of more than 15,000 full-length human and mouse cDNA sequences. Proc Natl Acad Sci U S A. 2002;99:16899-903.

21. Strehlow V, Heyne HO, Vlaskamp DRM, Marwick KFM, Rudolf G, de Bellescize J, Biskup S, Brilstra EH, Brouwer OF, Callenbach PMC, Hentschel J, Hirsch E, Kind PC, Mignot C, Platzer K, Rump P, Skehel PA, Wyllie DJA, Hardingham GE, van Ravenswaaij-Arts CMA, Lesca G, Lemke JR, Arzimanoglou A, Augustijn PB, Van Bogaert P, Bourry $H$, Burfeind $P$, Chu $Y$, Chung B, Doummar D, Edery P, Fattal-Valevski A, Fradin M, Gerard M, de Geus C, Gunning B, Hasaerts D, Helbig I, Helbig KL, Jamra R, Lyver MJ, Wassink-Ruiter JSK, Koolen DA, Lederer D, Lunsing RJ, Mathot M, Maurey H, Menascu S, Michel A, Mirzaa G, Mitter D, Muhle H, Møller RS, Nava C, O'Brien M, van Pinxteren-Nagler E, van Riesen A, Rougeot C, Sanlaville D, Schieving JH, Syrbe S, Veenstra-Knol HE, Verbeek N, Ville D, Vos YJ, Vrielynck P, Wagner S, Weckhuysen S, Willemsen MH. GRIN2A -related disorders: genotype and functional consequence predict phenotype. Brain. 2019;142:80-92.

22. Testa-Silva G, Verhoog MB, Goriounova NA, Loebel A, Hjorth J, Baayen JC, de Kock CPJ, Mansvelder HD. Human synapses show a wide temporal window for spike-timing-dependent plasticity. Front Synaptic Neurosci. 2010;2:12.

23. Testa-Silva G, Verhoog MB, Linaro D, de Kock CPJ, Baayen JC, Meredith RM, De Zeeuw Cl, Giugliano M, Mansvelder HD. High bandwidth synaptic communication and frequency tracking in human neocortex. PLoS Biol. 2014;12:e1002007.

24. Vargas-Caballero M, Willaime-Morawek S, Gomez-Nicola D, Perry VH, Bulters $D$, Mudher A. The use of human neurons for novel drug discovery in dementia research. Expert Opin Drug Discov. 2016;11(4). https://doi.org/10. 1517/17460441.2016.1154528.

25. Vargas-Caballero M, Robinson HPC. 2003. A slow fraction of Mg2+ unblock of NMDA receptors limits their contribution to spike generation in cortical pyramidal neurons. J Neurophysiol 89:2778-2783.

26. Verhoog MB, Goriounova NA, Obermayer J, Stroeder J, Hjorth JJJ, Testa-Silva G, Baayen JC, de Kock CPJ, Meredith RM, Mansvelder HD. Mechanisms underlying the rules for associative plasticity at adult human neocortical synapses. J Neurosci. 2013a;33:17197-208.

27. Walsh PS, Erlich HA, Higuchi R. Preferential PCR amplification of alleles: mechanisms and solutions. PCR Methods Appl. 1992;1:241-50. 
28. Yang X, Boehm JS, Yang X, Salehi-Ashtiani K, Hao T, Shen Y, Lubonja R, Thomas SR, Alkan O, Bhimdi T, Green TM, Johannessen CM, Silver SJ, Nguyen C, Murray RR, Hieronymus H, Balcha D, Fan C, Lin C, Ghamsari L, Vidal M, Hahn WC, Hill DE, Root DE. A public genome-scale lentiviral expression library of human ORFs. Nat Methods. 2011;8:659-61.

\section{Publisher's Note}

Springer Nature remains neutral with regard to jurisdictional claims in published maps and institutional affiliations.

Ready to submit your research? Choose BMC and benefit from:

- fast, convenient online submission

- thorough peer review by experienced researchers in your field

- rapid publication on acceptance

- support for research data, including large and complex data types

- gold Open Access which fosters wider collaboration and increased citations

- maximum visibility for your research: over $100 \mathrm{M}$ website views per year

At $\mathrm{BMC}$, research is always in progress. 